\title{
PECULIARITIES OF MINERAL NUTRITION OF CEREALS IN ALUMINUM-ACID SOIL CONDITIONS
}

\author{
Shikhova Lyudmila Nikolaevna
}

Doctor of Agricultural Sciences, Associate Professor, Head of the Department of Ecology and Zoology, Vyatka State Agricultural Academy

shikhola-1@mail.ru

Prosp. Oktyabrsky, 133, 610017 Kirov, Russian Federation

\section{Lisitsyn Evgeniy Mikhaylovich}

Doctor of Biological Sciences, Professor, Department of Ecology and Zoology, Vyatka State Agricultural Academy edaphic@mail.ru Prosp. Oktyabrsky, 133, 610010 Kirov, Russian Federation

\section{Batalova Galina Arkadyevna}

Doctor of Agricultural Sciences, Professor,

Head of the Department of Oats Breeding, Vyatka State Agricultural Academy

g.batalova@mail.ru

Prosp. Oktyabrsky, 133, 610017 Kirov, Russian Federation

\begin{abstract}
The influence of aluminum ions on requirements of plants of cereal crops (wheat Triticum aestivum L. and oats Avena sativa L.) in macronutrients is studied. In the first series of experiments it is revealed that doubling of a dose of phosphorus in the acid media has caused doubling of its inclusion in metabolic processes in aluminum-resistant wheat Irgina at early stages of development, but in aluminum-sensitive wheat Priokskaya - only at a flowering stage. The development of root systems in wheat varieties differ in their Al-resistance level in the conditions of full supply with nitrogen and potassium does not depend on the presence of ions of hydrogen, aluminum or phosphorus in soil. Aluminum-sensitive wheat variety is characterized by considerable dependence of photosynthesis on conditions of a mineral nutrition whereas the intensity of photosynthetic processes of aluminum-resistant variety is influenced basically by a development stage.

In the second series of experiments rather different reaction of the investigated wheat varieties on input of calcium into acid growth media is pointed out. These differences are related with transformation of absorbed phosphorus into mineral and organic acid-soluble fractions. Decreasing of ratio organic: mineral phosphorus indicates less intensiveness of metabolic processes in aluminum-resistant wheat Irgina at early stage of growth and following
\end{abstract}


increasing of these processes under liming. Opposite, sensitive wheat Priokskaya displays sharp decrease of metabolic activity by the termination of experiment under calcium input.

In the third plants of aluminum-resistant oats variety Krechet were capable to support metabolic processes with participation of nitrogen, phosphorus and potassium in the conditions of action of the stressful factor at the same level as in the neutral growth media. Changes of relative requirements in macronutrients specifies in considerable reorganizations of metabolic reactions in plants of Al-sensitive oats variety Argamak under stressor action. The biochemical processes related with action of the photosynthetic apparatus of leaves in stressful conditions have a priority in their supply with macronutrients, that is specified by smaller variability of the triple ratio $\mathrm{N}: \mathrm{P}: \mathrm{K}$ necessary for the maximum development of the leaves of oats in comparison with root systems at aluminum influence.

Key words: spring wheat, oats, aluminum, nitrogen, phosphorus, potassium.

\section{Introduction}

The stresses limiting plant growth on acid soils consist of proton rhizotoxicity (low $\mathrm{pH}$ ), nutrient deficiency (primarily phosphorus but also potassium, calcium, and other minerals), and metal toxicity (aluminum and manganese) [26]. Among these constraints, toxicity of exchangeable $\mathrm{Al}^{3+}$ ions is considered to be the major limiting factor at cultivation of plants on acid soils [24], a major factor reducing efficiency of plants on $67 \%$ of all acid soils [12].

Adequate entering of nutrients is necessary for efficient crop production. As the majority of acid sod-podzolic soils in natural state are deficient in primary nutrients, particularly, nitrogen and phosphorus [33], and the part of these elements become gradually depleted by crops removal, it is necessary to fill this shortage at the expense of external sources. However, this strategy has become economically less feasible with increase of production cost, especially in the soils demanding phosphoric fertilizers. Therefore, efforts of scientists are directed toward breeding of plants which are capable to receive the maximum nutrient elements from the soil and/or make this process more efficient.

Aluminum interferes with absorption, translocation and utilization of many essential nutrients necessary for a plant such as nitrogen, calcium, potassium, magnesium, and phosphorus [18; 37].

Nitrogen fertilizers are widely used for increasing productivity of grain crops and the protein content of grain in cereal crops. However it is necessary to optimize their use in order to decrease the risks of environmental contamination and production costs [27]. For that reason, the efficiency of use of nitrogen fertilizers by plants becomes a very important trait in studying and breeding of plants, including cereal $[10 ; 20]$. Increase of accumulation of nitrogen in plants not at the expense of increase of nitrogen fertilizers, but at the expense of creating genotypes with the better ability of their root systems to absorb nitrogen from soil becomes the core task in the decision of the problem. On the other hand, in order to get higher values of grain yield, that process should be followed by an increased intensity of photosynthesis. Otherwise high concentration of nitrogen in grain and straw will be reached with lowering in efficiency of nitrogen utilization [10]. As the percentage of acid soils is high throughout the world, so there is plenty of references dealing with parameters of metabolism of nitrogen on such soils [7] and considerable efforts are directed to establishment of genotypic specificity of parameters of a nitrogen metabolism [19;27].

Aluminum toxicity and phosphorus deficiency are two common constraints limiting crop production in acid soils [29]. Understanding the mechanisms underlying aluminum and phosphorus interactions will help to develop management principles to sustain production of agricultural plants in acid soils. Effects of phosphorus-aluminum interaction on adaptation of plants to toxicity of acid soils were studied in many research $[11 ; 25 ; 45 ; 50]$. Fukuda et al. [15] have assumed that a common metabolic system is responsive to both deficiency of phosphorus and to toxicity of aluminum in rice.

Increasing phosphorus supply substantially decreased extractable Al in bulk soil [23]. This decrease in aluminum ions extractability in soil is likely to have resulted from the chemical sedimentation of aluminum with the added 
phosphorus that leads to lowering the activity of trivalent aluminum ions in the soil solution [36;42].

The increasing entering of phosphorus can ameliorate the toxic effect of aluminum ions on root growth, but degree of the amelioration is dependent on the severity of the stress. High doses of phosphorus were more effective on influence on development of shoots than on the root systems. Very strong positive effect of entering of raising doses of phosphorus on shoot growth was found out at high level of stressful influence $(200 \mu \mathrm{M}$ aluminum) [25]. The key moment was that moving of aluminum ions from the roots to the shoot was markedly reduced at entering of $80 \mathrm{mg}$ of phosphorus per $\mathrm{kg}$ of soil. Irrespectively of the level of added aluminum, wheat seedlings were able to absorb more phosphorus from the soil, translocated more phosphorus to the shoots and utilize phosphorus more effectively for shoot growth and development with increase of level of entering phosphorus although total absorption of phosphorus decreased with the aluminum influence. Similar findings have been received previously in the conditions of nutrient solution cultures $[16 ; 26]$.

It has been suggested that immobilization of aluminum by phosphorus in cell wall of roots is a potential mechanism for Al-tolerance in buckwheat [50], barley [35], and maize [16]. Under Al stress in hydroponics phosphorus application was shown to stimulate malate exudation (an indicator of aluminum resistance) from the tap root tip of the P-efficient soybean (Glycine max) genotypes compared with the P-inefficient genotypes [7]. In field experiments with soybean [16] it is shown that phosphorus addition to acid soils stimulates aluminum resistance, especially for the genotypes capable of absorbing this macroelement effectively. Subsequent studies in hydroponic culture conditions have shown that solution $\mathrm{pH}$, levels of aluminum and phosphorus coordinately changed growth of roots of soybean and exudation of malate anions (as a basic mechanism of plant Al-resistance).

Iqbal et al. [50] assume at least four different ways in which phosphorus can lower toxicity of aluminum. Firstly, phosphorus directly reacts with aluminum in soil forming Al-P precipitates, and thus reduces activity of $\mathrm{Al}^{3+}$ ions in a soil solution. Secondly, phosphorus reduces the amount of apoplastic aluminum, that was bound to the root cell walls and this binding was around $37 \%$ of the total Al uptake by the root. Thirdly, high doses of entering of phosphorus reduce the total absorption of aluminum by plant (to $50 \%$ ), thus simultaneously its concentration in roots decreases to a lesser degree (12\%), than in shoots $(88 \%)$ with high degree of stress. And, at last, phosphorus reduces moving of aluminum from roots to shoots by up to $90 \%$ in high doses of phosphorus and aluminum.

The aluminum can reduce the absorption of potassium by competitive inhibition [35]. It has been found that the potassium deficiency, induced by aluminum, affects nitrogen metabolism by stimulating the accumulation of putrescine [28]. At Stylosanthes aluminum also increases the adsorption of nitrogen in tolerant species [34], leading to increases of nitrate, free amino acids and proteins contents in tissues [6]. This increase in nitrogen metabolism in tolerant species subjected to aluminum is related to the synthesis of specific proteins $[1 ; 9]$ that provides differential tolerance of plants to aluminum. Some researchers [6] have found that the toxic effects of aluminum are shown only when nitrogen is presented in nitric form. However, results of study [2] indicate that aluminum does not statistically influenced the growth rates of two Stylosanthes species when supplied with nitrate form of nitrogen fertilizer although under these conditions the tendency of decrease in relative growth rate in species $S$. guianensis is observed. In the presence of nitric nitrogen, aluminum increased potassium concentrations in $S$. macrocephala plants, but not in S. guianensis. When the nitrogen source was supplied by ammoniacal form, aluminum did not influence the adsorption of potassium in both species. In the presence of the nitric source, the aluminum increases the potassium concentrations only in the tolerant species, the $S$. macrocephala.

Thus, although mechanisms of interaction of aluminum and elements of a mineral nutrition of plants has been taken into consideration in a few studies on plant adaptation to acid soils, this subject is still quite poorly understood.

Agricultural use of fertilizers must be as optimal as possible for ensuring increase of plant productivity with the same or higher quality of products, and minimizing environment contamination by their surplus. Therefore it is necessary to optimize the ratio of all three basic macronutrients $(\mathrm{N}, \mathrm{P}$, and $\mathrm{K}$ ) in fertilizer simultaneously. However, this problem is 
connected with a considerable amount of variants under investigation. In a case of acid soils, presence of ions of exchangeable aluminum increases twice amount of variants of the experience necessary for finding-out of the put question.

Plant physiologists offered principally new approach in decision of the question - estimation of total $\mathrm{N}+\mathrm{P}+\mathrm{K}$ doze in fertilizer and an optimum of N:P:K ratio within this doze. This approach gives an exact approximation for optimum parity of nutrients in fertilizer and demands a little number of variants (10-15). Complexity of such research can be lowered even more, if a method of systematic variants [22] is used. The main advantage of a method is that only 3 variants are necessary for estimation the optimum N:P:K ratio. At studying influence of the stressful factor 3 more variants are added and, thus, total number of variants for each investigated variety of plants makes six.

Process of a mineral nutrition of plants is closely related with photosynthesis. A mineral nutrition provides the growing photosynthetic apparatus with building elements. Three main components of plant productivity of cereal crops - number of productive stems, number of grains per ear (panicle) and 1000 grain mass - positively influence increase in photosynthesis intensity at stages of formation of these components. The positive interrelation between intensity of $\mathrm{CO}_{2}$ digestion and the specific leaf area (SLA) is an important regularity of varietal variability of photosynthesis. The heightened content of chlorophyll in plant leaves is also related with the heightened plant productivity or quality of product [49]. These characters are stable enough for a genotype, but under influence of edaphic factors they change in different degree. Change of the ratio of mineral elements in fertilizer can change considerably the reaction of the photosynthetic apparatus to stressful influence of aluminum. Moreover, differences in aluminum tolerance level between plants are often related with their ability to use phosphorus fertilizer under acid growth conditions.

Thus, the main tasks of a given study were: a) to establish aluminum influence in acid soil on modification of requirement of plants of grain crops in the basic macronutrients, and b) to estimate influence of soil acidity on uptake of phosphorus by plants and its transformation into organic and mineral compounds within whole plants.

\section{Materials and methodology}

\section{Influence of soil acidity on the content of phosphoric complexes in wheat plants.}

In the conditions of acid reaction of growth medium pot experiment with two spring wheat varieties is put: Irgina - aluminum-resistant variety, and Priokskaya - aluminum-sensitive variety. Reaction of the varieties on aluminum influence was estimated in laboratory with a method described earlier [31]. The natural sod-podzolic soil $\left(\mathrm{pH}_{\mathrm{KCl}} 3.97\right.$, hydrolytic acidity $=2.48 \mathrm{mg}$-equivalent / $100 \mathrm{~g}$ of soils) containing $16 \mathrm{mg}$ of exchangeable aluminum per $100 \mathrm{~g}$ of soils and $1.7 \mathrm{mg}$ of phosphorus per $100 \mathrm{~g}$ of soils (at extraction with $0.2 \mathrm{H} \mathrm{HCl}$ ) was used. Plants grew up in pots with $4 \mathrm{~kg}$ of soil in triple replications on 4 nutrition backgrounds.

Optimum doses of nitrogen and potassium were calculated according to [39]: nitrogen $120 \mathrm{mg} / 1$, potassium - $150 \mathrm{mg} / \mathrm{l}$ of a nutrient solution. Phosphorus was brought in quantity equal to the aluminum content in soil (variant $\mathrm{NP}_{1} \mathrm{~K}$ ), at the double by aluminum content in soil (variant $\mathrm{NP}_{2} \mathrm{~K}$ ). For calculation of quantity of the phosphorus precipitated with aluminum, tables of recalculation were used [3]. Considering that $4 \mathrm{~kg}$ of soil correspond to 101 of a solution, following quantities of nutritious salts $(\mathrm{g} / \mathrm{pot})$ were taken (Table 1).

Table 1

Entering of nutritious salts for creation of nutrient backgrounds, g/pot

\begin{tabular}{|l|c|c|c|}
\hline \multicolumn{1}{|c|}{ Nutrient background } & $\mathrm{NH}_{4} \mathrm{NO}_{3}$ & $\mathrm{KCl}$ & $\mathrm{KH}_{2} \mathrm{PO}_{4}$ \\
\hline The control (natural soil) & - & - & - \\
\hline The control $+\mathrm{NK}$ & 3.43 & 1.43 & - \\
\hline The control $+\mathrm{NP}_{1} \mathrm{~K}$ & 3.43 & - & 2.59 \\
\hline The control $+\mathrm{NP}_{2} \mathrm{~K}$ & 3.43 & 2.87 & 5.17 \\
\hline
\end{tabular}


Fertilizers were input in the form of chemically pure salts one week prior to sowing. Sowing was carried out with 15 dry seeds per pot and 10 most vigorous seedlings have been left after germination. Each variant had 12 pots in total. Samples for estimation of a chlorophyll content and fractional structure of phosphates consisted of the mixed plant sample ( 3 pots with 10 plants each per each variant of study). Estimation of the basic fractions of phosphorus was spent according to [38] after wet combustion. Selection of plants for the analysis was carried out at three growth stages: tillering, leaf-tube formation, and flowering. The content of a chlorophyll is defined in acetone extract with "SHIMADZU UVmini1240" spectrophotometer by a [30] technique.

2. Influence of liming on uptake and transformation of phosphorus compounds within wheat plants.

Liming is one of the most effective means of decreasing negative influence of soil acidity on agricultural crops, so as the extension of a previously described experiments, additional variant with use of liming according to hydrolytic acidity of soil was used. Estimation of basic phosphorus fraction was spent three times per growth season - at tillering, leaf-tube formation, and flowering stages on the same spring soft wheat varieties: Irgina - aluminum-resistant variety, and Priokskaya - aluminum-sensitive variety.

3. Influence of aluminum-acid growth media on modification of requirement of oats plants in the basic macronutrients.

Plants were grown up in the conditions of sand culture. 15 dry seeds were sown in pots with $4 \mathrm{~kg}$ of sand each and 8 most vigorous seedlings have been left after germination. In this study 2 oat varieties were investigated - Krechet (Alresistant) and Argamak (Al-sensitive) [32]. Duration of the study has made 30 days according to the literary data $[8 ; 14]$.

The content of micronutrients was estimated in mg-atoms, instead of weight quantities of "acting matter" $\left(\mathrm{N}, \mathrm{P}_{2} \mathrm{O}_{5}, \mathrm{~K}_{2} \mathrm{O}\right)$ as it is accepted in agronomical practice. Content of real atoms (ions $\mathrm{NO}^{3-} \mathrm{NH}^{4+}, \mathrm{PO}_{4}{ }^{3-} \mathrm{K}^{+}$, or atoms $\mathrm{N}, \mathrm{P}, \mathrm{K}$ ) absorbed by roots is more important for plants than the contents of conditionally "acting matters". One kg of each of "acting matter" will contain the different quantity of atoms. Application of step schemes of change of quantity of input fertilizers (for example, 30:30:30, 60:60:60 and so on) leads to disturb ance of the requirement of "only distinction" between variants as it changes not only quantity of input substances, but also ratio in number of input atoms of each element. Besides, "acting matters" include different amount of oxygen atoms, which is not taken into account. Therefore D.B. Vakhmistrov, V.A. Vorontsov [47] suggest to count a ratio of elements in mg-atoms, and in all variants of experiment the total content of elements should be identical and correspond to their sum in standard Hogland-Arnon-1 medium (22 mg-atom per 1 liter of a solution).

Thus, research consisted of three variants at neutral reaction of growth medium $(\mathrm{pH}=6.5)$, and the same three variants at acid reaction $(\mathrm{pH}=4.3+1 \mathrm{mM}$ aluminum in the form of sulphate): $\mathrm{N}: \mathrm{P}: \mathrm{K}=70: 15: 15$ atomic \%, $\mathrm{N}: \mathrm{P}: \mathrm{K}=15: 70: 15$ atomic $\%$, and $\mathrm{N}: \mathrm{P}: \mathrm{K}=$ $=15: 15: 70$ atomic $\%$. Total $\mathrm{N}+\mathrm{P}+\mathrm{K}$ content are equal to $22 \mathrm{mg}$-atom per $1 \mathrm{~kg}$ of substrate. Each variant of experiment is put in four replications. Upon termination of experiments dry weight of roots and shoots, the total and specific leaf area, and the chlorophyll content were estimated.

Each experiment is repeated twice within two years. Thus, the data resulted in tables, represents average value from 12-16 replications (34 biological replications $\times 2$ replications in each year $\times 2$ years). Statistical calculations and an estimation of an optimum ratio of macronutrients in growth media are spent according to [46]. Accuracy of experiment made 2.6-3.2\% depending on the year.

\section{Results and discussion}

\section{Influence of phosphorus on plant resistances to high soil acidity.}

Results of estimation of content of various fractions of phosphoric complexes in leaves of spring wheat are presented in Table 2 .

The data about a ratio of organic and inorganic forms of phosphoric complexes which serves as an indicator of intensity of inclusion of phosphorus in exchange processes of an organism is most interesting to researchers and breeders. It is possible to indicate that input of nitrogen, phosphorus and potassium into acid soil at tillering stage of growth has lowered intensity of phosphorus metabolization though for Al-sensitive variety it has occurred only at the doubled dose of phosphorus. At the following stages of 
development, in contrary, improvement of a mineral nutrition promotes the strengthened inclusion of phosphorus in a metabolism, and it is manifested much more strongly in Al-resistant variety.

Doubling of the dose of phosphorus has caused doubling of its inclusion in exchange processes in a resistant variety at early growth stages, but in sensitive variety - only on a flowering stage. This finding indicates higher level of a metabolism in Al-resistant variety at early stages of growth. At first two stages of development input of nitrogen and potassium into soil was more effective for phosphorus metabolization than input of phosphorus at nitrogen and potassium background.

Synthesis of organic acid-soluble phosphorus (in $\%$ of the total phosphorus content) in the course of growth raises constantly, and at tillering stage it is more strongly shown in aluminum-sensitive variety, but at the following stages of growth the resistant variety catches up sensitive variety and even overtakes it a little on the given parameter.

If to compare the content of total phosphorus in shoots of contrast varieties in absolute $(\mathrm{g})$ instead of relative ( $\mathrm{g} / \mathrm{g}$ of dry matter) values, that is to consider higher shoot mass of Alresistant variety, is possible to suggest that resistant variety takes significantly more amount of phosphorus from soil, than sensitive variety.

At a tillering stage there are no distinctions between varieties on biomass accumulation on all nutrient backgrounds, thus improvement of nutrition leads to double increase of a biomass of plants (Table 3 ).

At a leaf-tube formation stage differences between varieties were not revealed also, but differences on nutrition backgrounds were considerably shown. The doubled dose of phosphorus has led 1.5-2 fold increase in plant productivity. However plants of a control background have strongly grown up by this stage also that was especially shown in aluminumresistant variety. Varietal differences were especially shown at flowering stage on all nutrition backgrounds; resistant variety has appeared much more productive than sensitive one.

The particular interest represents the fact that entering of phosphoric fertilizers both into one- and in double dose has led to almost identical strengthening of accumulation of dry matter by both varieties (both NPK backgrounds in

Table 2

Influence of nutrient backgrounds on the content of phosphorus forms in leaves of spring wheat, $\mathrm{g} / \mathrm{g}$ of fresh mass

\begin{tabular}{|c|c|c|c|c|c|c|}
\hline \multirow[t]{2}{*}{ Nutrient background } & \multicolumn{2}{|c|}{ Tillering stage } & \multicolumn{2}{|c|}{$\begin{array}{l}\text { Leaf-tube formation } \\
\text { stage }\end{array}$} & \multicolumn{2}{|c|}{ Flowering stage } \\
\hline & $1 *$ & 2 & 1 & 2 & 1 & 2 \\
\hline \multicolumn{7}{|c|}{ Mineral phosphorus } \\
\hline Control & 0.04 & 0.04 & 0.07 & 0.03 & 0.02 & 0.04 \\
\hline Control + NK & 0.04 & 0.02 & 0.03 & 0.05 & 0.03 & 0.04 \\
\hline Control + $\mathrm{NP}_{1} \mathrm{~K}$ & 0.05 & 0.04 & 0.06 & 0.04 & 0.04 & 0.03 \\
\hline Control $+\mathrm{NP}_{2} \mathrm{~K}$ & 0.02 & 0.05 & 0.03 & 0.05 & 0.02 & 0.01 \\
\hline \multicolumn{7}{|c|}{ Organic acid-soluble phosphorus } \\
\hline Control & 0.55 & 0.35 & 0.20 & 0.24 & 0.24 & 0.28 \\
\hline Control + NK & 0.34 & 0.22 & 0.50 & 0.41 & 0.27 & 0.28 \\
\hline Control $+\mathrm{NP}_{1} \mathrm{~K}$ & 0.32 & 0.43 & 0.39 & 0.33 & 0.52 & 0.43 \\
\hline Control $+\mathrm{NP}_{2} \mathrm{~K}$ & 0.20 & 0.40 & 0.34 & 0.44 & 0.34 & 0.26 \\
\hline \multicolumn{7}{|c|}{ Organic acid-insoluble phosphorus } \\
\hline Control & 0.14 & 0.11 & 0.11 & 0.05 & 0.08 & 0.07 \\
\hline Control + NK & 0.11 & 0.08 & 0.11 & 0.11 & 0.09 & 0.06 \\
\hline Control $+\mathrm{NP}_{1} \mathrm{~K}$ & 0.12 & 0.09 & 0.10 & 0.09 & 0.03 & 0.03 \\
\hline Control $+\mathrm{NP}_{2} \mathrm{~K}$ & 0.12 & 0.09 & 0.10 & 0.07 & 0.02 & 0.02 \\
\hline \multicolumn{7}{|c|}{ Total phosphorus } \\
\hline Control & 0.73 & 0.50 & 0.37 & 0.33 & 0.34 & 0.39 \\
\hline Control + NK & 0.49 & 0.32 & 0.64 & 0.57 & 0.36 & 0.38 \\
\hline Control $+\mathrm{NP}_{1} \mathrm{~K}$ & 0.49 & 0.56 & 0.55 & 0.45 & 0.59 & 0.49 \\
\hline Control $+\mathrm{NP}_{2} \mathrm{~K}$ & 0.34 & 0.53 & 0.47 & 0.56 & 0.37 & 0.29 \\
\hline
\end{tabular}

Note. * 1 - variety Irgina; 2 - variety Priokskaya. 
comparison with NK background). In other words, differences in resistance to aluminum have not affected action of phosphoric fertilizers. The same conclusion arises at the analysis of accumulation of a biomass of an underground part of plants that is development of root systems of plants contrast on Al-resistance level in the conditions of supply with nitrogen-andpotassium nutrition depends a little on presence of ions of hydrogen, aluminum or phosphorus in soil. The analysis of growth of plants on natural acid soil (control background) has allowed to show differences in schemes of development of the investigated varieties.

Though both varieties as a whole have shown great advance of a gain of roots from tillering stage to leaf-tube formation stage, and in a gain of shoot - from tillering stage to flowering phase, absolute value of a gain both roots and shoots is much more for aluminumresistant variety. In other words, in acid soil resistant variety increases root mass more intensively at the beginning of growth that, possibly, allows it to increase shoot mass more intensively too.
Summarizing the above-stated it is possible to point out that selection of plants on acid soils can be conducted on development of root system at leaf-tube formation stage already, but on development of shoot mass - not earlier than a flowering stage.

It is known that autotrophic growth of organisms is provided, on the one hand, at the expense of root nutrition and, on the other hand, at the expense of assimilation of carbon of air in the course of photosynthesis. These two processes in an organism are interrelated and interdependent; synthesis of elements of the photosynthetic apparatus depends on absorption of necessary mineral substances from soil.

At the analysis of wheat varieties contrast on Al-resistance level it is revealed that in the control background (acid soil) resistant variety synthesized higher quantity of chlorophyll (chlorophyll $a, b$ and their sums), than sensitive variety at all investigated stages of development (Table 4).

Obviously the given parameter (content of chlorophyll per gram of dry mass) as index of resistance to lowered $\mathrm{pH}$ of soil solution requires

Table 3

Influence of nutrition backgrounds on accumulation of the total biomass by spring wheat, g of dry mass per 1 plant

\begin{tabular}{|l|c|c|c|c|c|c|}
\hline \multirow{2}{*}{ Nutrition background } & \multicolumn{2}{|c|}{ Tillering stage } & \multicolumn{2}{c|}{$\begin{array}{c}\text { Leaf-tube formation } \\
\text { stage }\end{array}$} & \multicolumn{2}{c|}{ Flowering stage } \\
\cline { 2 - 7 } & $1^{*}$ & 2 & 1 & 2 & 1 & 2 \\
\hline Control & 0.095 & 0.112 & 0.327 & 0.271 & 0.527 & 0.438 \\
\hline Control $+\mathrm{NK}$ & 0.185 & 0.206 & 0.391 & 0.399 & 0.691 & 0.479 \\
\hline Control $+\mathrm{NP}_{1} \mathrm{~K}$ & 0.172 & 0.202 & 0.439 & 0.468 & 0.710 & 0.562 \\
\hline Control $+\mathrm{NP}_{2} \mathrm{~K}$ & 0.202 & 0.199 & 0.608 & 0.624 & 0.906 & 0.655 \\
\hline
\end{tabular}

Note. * 1 - variety Irgina; 2 - variety Priokskaya.

Table 4

Influence of nutrition backgrounds on the total content of chlorophyll in leaves of spring wheat, $\mathrm{mg} / \mathrm{g}$ of dry mass

\begin{tabular}{|l|c|c|c|c|c|c|}
\hline \multirow{2}{*}{$\begin{array}{c}\text { Nutrition } \\
\text { background }\end{array}$} & \multicolumn{2}{|c|}{ Tillering stage } & \multicolumn{2}{c|}{$\begin{array}{c}\text { Leaf-tube formation } \\
\text { stage }\end{array}$} & \multicolumn{2}{c|}{ Flowering stage } \\
\cline { 2 - 7 } & $1^{*}$ & 2 & 1 & 2 & 1 & 2 \\
\hline Control & 7.51 & 6.80 & 6.30 & 5.59 & 3.63 & 3.24 \\
\hline Control $+\mathrm{NK}$ & 6.99 & 8.30 & 3.59 & 3.85 & 3.31 & 2.87 \\
\hline Control $+\mathrm{NP}_{1} \mathrm{~K}$ & 6.85 & 9.40 & 3.61 & 4.78 & 2.01 & 2.89 \\
\hline Control $+\mathrm{NP}_{2} \mathrm{~K}$ & 6.98 & 7.37 & 3.03 & 4.11 & 2.09 & 2.50 \\
\hline
\end{tabular}

Note. * 1 - variety Irgina; 2 - variety Priokskaya. 
more detailed research on much number of varieties in field conditions.

Other interesting fact which is necessary to note in respect of influence of nutrition backgrounds: at input of phosphoric fertilizers into soil Al-sensitive variety synthesizes much more quantity of all forms of chlorophyll than resistant variety at all stages of development. In other words, at improvement of conditions of mineral nutrition compensation mechanisms of plants limit excessive power consumption and plastic substances on construction of the photosynthetic apparatus as receipt of substances and energy raises at the expense of root system.

Thus, if the resistant variety reduces the content of chlorophyll already at tillering stage then in sensitive variety decrease begins only at leaf-tube formation stage, besides decrease in synthesis of chlorophyll in resistant variety occurs much more sharply. It can testify higher plasticity of a metabolism of aluminum-resistant variety - it reacts to change of environment conditions much faster.

The parameter of specific leaf area (SLA) indirectly characterizes a thickness of leaf and a share of dry matter in it. Influence of input of phosphorus on the given parameter in our experiments was differing for the investigated varieties. Strengthening of a phosphoric nutrition has led to increase of an average SLA of all leaves of plants of both varieties at tillering stage (a background with a double dose of phosphorus), to its increase in resistant variety at leaf-tube formation stage and to drop at flowering phase whereas in sensitive variety, on the contrary, strengthening of a phosphoric nutrition has lowered this parameter at leaf-tube formation stage and has strengthened at flowering stage (in comparison with natural acid background and background with one dose of phosphorus) (Table 5).

This data indicates considerable differences in a metabolism of the studied varieties: at flowering stage resistant variety has strengthening of outflow of plastic substances from leaves into generative organs whereas a sensitive variety has not complete formation of the leaf apparatus by this time and continued to increase it to the detriment of generative organs.

Results of the two-way ANOVA have allowed to calculate shares of influence of growth stage and nutrition backgrounds on change of SLA. Nutrition backgrounds have rendered twice a greater influence on SLA variability in sensitive variety (influence of factors "nutrition background" + "nutrition background x growth stage" $=61 / 9 \%$ against $27.5 \%$ in resistant variety). Thus, sensitive variety is characterized by considerable dependence of photosynthesis on conditions of mineral nutrition whereas intensity of photosynthetic processes in resistant variety is influenced basically by growth stage.

2. Influence of liming on uptake and transformation of phosphorus compounds within wheat plants.

The content of the total phosphorus during growth season at the backgrounds without fertilizers and liming decreased gradually at aluminum resistant wheat Irgina (except mineral phosphorus) whereas at sensitive wheat Priokskaya it raised in time at the expense of almost all forms of complexes, except for acid-insoluble fraction (Table 6).

At plants of aluminum resistant wheat the share of mineral complexes in total phosphorus content increased from 17 (tillering stage) up to $30 \%$ (leaf-tube formation stage), at sensitive

Table 5

Influence of nutrition backgrounds on specific leaf area of spring wheat varieties, contrast on Al-resistance, $\mathrm{mg} / \mathrm{sm}^{2}$

\begin{tabular}{|l|c|c|c|c|c|c|}
\hline \multirow{2}{*}{ Nutrition background } & \multicolumn{2}{|c|}{ Tillering stage } & \multicolumn{2}{c|}{$\begin{array}{c}\text { Leaf-tube formation } \\
\text { stage }\end{array}$} & \multicolumn{2}{c|}{ Flowering stage } \\
\cline { 2 - 7 } & $1^{*}$ & 2 & 1 & 2 & 1 & 2 \\
\hline Control & 2.51 & 2.67 & 3.47 & 3.49 & 4.18 & 2.41 \\
\hline Control $+\mathrm{NK}$ & 2.33 & 2.37 & 4.21 & 4.83 & 4.19 & 4.54 \\
\hline Control $+\mathrm{NP}_{1} \mathrm{~K}$ & 2.43 & 2.47 & 3.76 & 3.20 & 4.27 & 2.91 \\
\hline Control $+\mathrm{NP}_{2} \mathrm{~K}$ & 3.28 & 3.06 & 3.94 & 3.17 & 3.06 & 4.45 \\
\hline
\end{tabular}

Note. * 1 - variety Irgina (Al-resistant); 2 - variety Priokskaya (Al-sensitive). 


\section{ТЕХНИКО-ТЕХНОЛОГИЧЕСКИЕ ИННОВАЦИИ}

wheat - remained a constant at level of $24 \%$. Liming increased the absolute content of mineral phosphates, thus a little if their relative share in phosphatic fund of a resistant variety increased only in a tillering stage (up to $25 \%$ ) then at a sensitive variety growth of a share of mineral phosphorus up to $30-33 \%$ is marked both in the beginning, and in the end of experiment.

Organic acid-soluble phosphorus complexes are most closely linked with synthetic processes at plants; they are the most mobile complexes of this element and are presented with nucleotides and carbohydrate-phosphates. On an early stage of development of aluminum resistant wheat the content of this fraction reaches $53 \%$ from the general pool of phosphorus, whereas at sensitive variety - $42 \%$ only. Liming reduces a share of these compounds to 38 and $33 \%$, accordingly. In later stages the quantity of acid-soluble organic fractions at resistant variety decreases gradually in a control variant (to $48 \%$ ), and its share raises to the same level at liming. At sensitive variety by the end of experiment the content of acid-soluble phosphorus increases, but in a variant with liming it remains on level $10 \%$ below the control.

Dynamics of influence of calcium on the content of acid-insoluble fractions of phosphorus at both varieties is similar as a whole: it decreases gradually; at the first stage of growth calcium considerably strengthens phosphorus transformation into acid-insoluble compounds, and by the end of experiment there is an alignment of indicators of a share of this fraction in the total phosphorus in both variants of experiment.

Thus, distinctions in reaction of wheat varieties with various level of aluminum resistance on calcium entering are reflected mainly in the content of mineral and organic acid-soluble phosphorus fractions.

Decrease in sizes of ratio of organic and mineral forms testifies to smaller intensity of exchange processes under liming conditions at aluminum resistant wheat variety in a tillering stage and gradual increase of these processes under the influence of calcium at later stages. Unlike it, the sensitive variety by the end of experiment had a sharp decrease in intensity of a metabolism at calcium entering.

3. Influence of aluminum on modification of oat plants' requirement in the basic macronutrients.

The study of mechanisms and genetic basis of aluminum resistance of agricultural plants and creating of varieties with high level of this type of resistance becomes more actual in relation to a drop in volumes of soil liming and, accordingly, increase in the areas of acid soils all over the world. However, presence of exchangeable $\mathrm{Al}^{3+}$ ions in

Table 6

Input and transformation of phosphorus compounds into wheat plants under action of lime, $\%$ of total dry mass

\begin{tabular}{|c|c|c|c|c|c|c|}
\hline \multirow[t]{3}{*}{ Variety } & \multirow{3}{*}{$\begin{array}{l}\text { Addition } \\
\text { of } \mathrm{Ca}\end{array}$} & \multicolumn{5}{|c|}{$\mathrm{P}_{2} \mathrm{O}_{5}$} \\
\hline & & \multirow{2}{*}{$\begin{array}{c}\text { Total } \\
\text { phosphorus }\end{array}$} & \multirow{2}{*}{$\begin{array}{c}\text { Mineral } \\
\text { phosphorus }\end{array}$} & \multicolumn{2}{|c|}{ Organic } & \multirow{2}{*}{$\begin{array}{c}\text { Organic/ } \\
\text { mineral }\end{array}$} \\
\hline & & & & $\begin{array}{l}\text { acid-soluble } \\
\text { phosphorus }\end{array}$ & $\begin{array}{l}\text { acid-insoluble } \\
\text { phosphorus }\end{array}$ & \\
\hline \multicolumn{7}{|c|}{ Tillering stage } \\
\hline \multirow[t]{2}{*}{ Irgina } & 0 & 0.364 & 0.064 & 0.193 & 0.107 & 4.7 \\
\hline & $\mathrm{Ca}$ & 0.348 & 0.088 & 0.134 & 0.126 & 3.0 \\
\hline \multirow[t]{2}{*}{ Priokskaya } & 0 & 0.329 & 0.078 & 0.141 & 0.110 & 3.2 \\
\hline & $\mathrm{Ca}$ & 0.256 & 0.078 & 0.085 & 0.093 & 2.3 \\
\hline \multicolumn{7}{|c|}{ Leaf-tube formation stage } \\
\hline \multirow[t]{2}{*}{ Irgina } & 0 & 0.348 & 0.067 & 0.192 & 0.089 & 4.2 \\
\hline & $\mathrm{Ca}$ & 0.392 & 0.092 & 0.170 & 0.126 & 3.2 \\
\hline \multirow[t]{2}{*}{ Priokskaya } & 0 & 0.370 & 0.089 & 0.166 & 0.111 & 3.1 \\
\hline & $\mathrm{Ca}$ & 0.392 & 0.096 & 0.189 & 0.107 & 3.1 \\
\hline \multicolumn{7}{|c|}{ Flowering stage } \\
\hline \multirow[t]{2}{*}{ Irgina } & 0 & 0.326 & 0.097 & 0.158 & 0.071 & 2.4 \\
\hline & $\mathrm{Ca}$ & 0.396 & 0.114 & 0.193 & 0.089 & 2.5 \\
\hline \multirow[t]{2}{*}{ Priokskaya } & 0 & 0.462 & 0.108 & 0.250 & 0.104 & 3.3 \\
\hline & $\mathrm{Ca}$ & 0.416 & 0.136 & 0.176 & 0.104 & 2.1 \\
\hline
\end{tabular}


growth medium determined low $\mathrm{pH}$ of these soils is not the sole stressful edaphic factor. Not the smaller role is played by shortage of some elements of a mineral nutrition and absence of a proper ratio between them. The sand culture allows to simulate soil key parameters, abstracting from complexity of this natural medium of plant habitat linked with features of mineral, salt structure, presence of organic structures and microbiological activity. The estimation of relative level of aluminum resistance in laboratory and greenhouse experiments was carried out by different researchers which used various nutrient solutions. The content and ratio of elements of a mineral nutrition in used media is so different sometimes that can mask exact action of the aluminum. So, the particular ratio of nitrogen, phosphorus and potassium (in mg-atoms per liter of solution) makes the following values: [43] 54:0:46; [48] - 77:5:18; [17] - 64.5:0.5:35; [13] (Steinberg's solution) - 87:1:12. Standard Hogland-Arnon-1 medium [21] contains the specified elements in the ratio 68:5:27. Probably, such considerable distinctions in the ratio of the basic macronutrients can affect a comparative estimation of Al-resistance level of plant varieties.

Using of Homes' method [22] for an estimation of optimum N:P:K ratio in a condition of sand culture for oat varieties differing in their reaction to aluminum, has shown that resistance nhich can be explained by a higher degree of resistance of metabolic processes (maintenance of balance between synthetic and catabolic reactions) which was testified by smaller changes of relative need in macronutrients under stress (Table 7).

$\mathrm{Al}$ stress had little influence on the ratio of metabolic/catabolic processes in the roots of the resistant oats variety Krechet. Of course, the total level of reactions of synthesis and destruction can change (increase or decrease), but in equal degrees. Metabolic activity of roots of a sensitive variety Argamak has changed considerably: the requirement for phosphorus has increased by 2.5 times, and requirement in potassium has decreased by 1.5 times. These changes can mean that some biochemical processes have been switched from the basic metabolic pathway to some other.

Development of aboveground mass under stressful influence has also shown distinction between the varieties. If the resistant variety demanded increase in a relative share of phosphorus (at the expense of nitrogen) at constant requirement in potassium the sensitive variety has changed relative shares of all three elements (requirement for nitrogen and phosphorus have increased by 1.3 and 2.2 times, accordingly, at the expense of requirement reduction in potassium by 1.7 times). The forming of the maximum leaf area of a resistant variety has demanded relative increase in a share of phosphorus and reduction in share of potassium in the growth medium at the constant content of nitrogen, but for a sensitive variety the requirement for nitrogen has increased, and the requirement for other elements has decreased. Modification of requirements of the leaf apparatus in macronutrients has not affected processes of synthesis of a chlorophyll neither at resistant, nor at a sensitive variety. Thus the interrelation between $\mathrm{N}, \mathrm{P}$ and $\mathrm{K}$ at which the process of synthesis of photosynthetic pigments was maximum at a resistant variety actually coincides with the ratio of the macronutrients necessary for the maximum development of root system both in

Table 7

Optimum ratio of nitrogen, phosphorus and potassium for some indicators of development of plants of two oats varieties, contrast on aluminum-resistance, \%

\begin{tabular}{|l|c|c|c|c|c|c|}
\hline $\begin{array}{c}\text { pH of } \\
\text { growth } \\
\text { media }\end{array}$ & $\begin{array}{c}\text { Root dry } \\
\text { mass }\end{array}$ & $\begin{array}{c}\text { Shoot dry } \\
\text { mass }\end{array}$ & $\begin{array}{c}\text { Total dry } \\
\text { mass }\end{array}$ & $\begin{array}{c}\text { Specific } \\
\text { leaf area }\end{array}$ & $\begin{array}{c}\text { Total leaf } \\
\text { area }\end{array}$ & $\begin{array}{c}\text { Total content } \\
\text { of } \\
\text { chlorophyll }\end{array}$ \\
\hline \multicolumn{7}{|c|}{ Variety Krechet (Al-resistant) } \\
\hline pH 6.5 & $46: 25: 29$ & $45: 18: 37$ & $45: 19: 36$ & $30: 43: 28$ & $46: 15: 39$ & $49: 20: 31$ \\
pH 4.3 & $43: 25: 32$ & $29: 34: 37$ & $33: 31: 36$ & $24: 41: 35$ & $45: 32: 23$ & $47: 17: 36$ \\
\hline \multicolumn{7}{|c|}{ Variety Argamak (Al-sensitive) } \\
\hline pH 6.5 & $46: 9: 45$ & $36: 10: 54$ & $39: 9: 52$ & $33: 35: 32$ & $23: 30: 47$ & $51: 22: 27$ \\
pH 4.3 & $45: 25: 30$ & $46: 22: 32$ & $48: 21: 31$ & $29: 44: 27$ & $47: 18: 35$ & $54: 23: 23$ \\
\hline
\end{tabular}


neutral, and in the acid growth condition. It can indicate the greater level of coordination of processes of a mineral nutrition and photosynthesis at aluminum-resistant oat variety than at a sensitive one.

However, from our point of view, more interesting is the fact that mathematically it is possible to calculate that ratio between macronutrients at which plants will not suffer depression of growth under the influence of the stressful factor. If we take into account the relation of dry weights of different parts of a plant (i.e. root-to-shoot ratio) or all plant in the control and in the test treatment thus their maximum ratio $(100 \%)$ will correspond to optimum N:P:K ratio.

In our case the following optimum N:P:K ratio are received for oat varieties Krechet and Argamak: for absence of depression of root growth $-30: 34: 36$ and 36:10:54, accordingly; for absence of depression of shoot growth - 18:52:30 and 31:11:58, accordingly; for a total mass of plants $-21: 49: 30$ and 32:11:57, accordingly.

\section{The conclusion}

Doubling of a phosphorus dose in the growth medium has caused doubling of its inclusion in metabolic processes in Al-resistant wheat variety at early growth stages already, but in sensitive variety phosphorus inclusion amplified only at flowering stage. At first two stages of development addition of nitrogen and potassium into soil is more effective for phosphorus metabolization than input of phosphorus salt at nitrogen and potassium background.

Development of root systems in plants of wheat varieties contrast on aluminum resistance level in the conditions of supply with nitrogen and potassium nutrition depends a little on presence of ions of hydrogen, aluminum or phosphorus in soil.

Aluminum-sensitive variety of wheat is characterized by considerable dependence of photosynthesis on conditions of mineral nutrition whereas intensity of photosynthetic processes in aluminum-resistant variety is influenced basically by a growth stage.

Different reaction of the investigated wheat varieties on input of calcium into acid growth media is related with transformation of absorbed phosphorus into mineral and organic acid-soluble fractions. Decreasing of ratio organic : mineral phosphorus indicates less intensiveness of metabolic processes in aluminum-resistant wheat Irgina at early stage of growth and following increasing of these processes under liming. Opposite, sensitive wheat Priokskaya displays sharply decrease of metabolic activity by the termination of experiment under calcium input.

Al-resistant oat variety maintained relative levels of $\mathrm{N}, \mathrm{K}$ and $\mathrm{P}$ metabolism (increased or decreased them by equal extent) in roots under stress condition. Possibly, it occurs at the expense of modification of nitrogen and phosphorus metabolism in shoots. The Al-sensitive variety of oat under conditions of aluminum influence keeps $\mathrm{N}$-metabolism level in roots, but levels of phosphorus and potassium metabolism are exposed to significant modifications. In shoots there is a reorganization of the metabolic processes occurring to participation of all three elements.

Choosing a certain ratio of elements of a mineral nutrition made it possible to reach a situation when aforementioned parameters will not expose negative action of aluminum on their development.

\section{ABBREVIATIONS}

$\mathrm{Al}$ - aluminum

$\mathrm{K}$ - potassium

LAR - leaf area ratio, the ratio of total leaf area to stem or twig mass

LWR - leaf weight ratio, ratio of leaf mass to total plant mass

$\mathrm{N}$ - nitrogen

$P$ - phosphorus

SLA - specific leaf area, one-sided area of a fresh leaf, divided by its oven-dry mass

Two-Way ANOVA - Analysis Of VAriance between groups with two factors

$\mathrm{CO}_{2}$ - carbon dioxide

\section{REFERENCES}

1. Amaral J.A.T. do, Cordeiro A.T., Rena A.B. Efeitos do alumínio, nitrato e amônio sobre a composição de metabólitos nitrogenados e de carboidratos. Stylosanthes guianensis e $S$. macrocephala. Pesquisa Agropecuária Brasileira, 2000, vol. 35, no. 2, pp. 313-320.

2. Amaral J.A.T. do, Rena A.B., Cordeiro A.T., Schmildt E.R. Effects of Aluminum, Nitrate and 
Ammonium on the Growth, Potassium Content and Composition of Amino Acids. Stylosanthes. IDESIA (Chile), 2013, vol. 31, no. 2, pp. 61-68.

3. Arinushkina E.V. Guide on chemical analysis of soil. Moscow, Moscow University Press, 1970. 491 p.

4. Baron A.A., Bakhracheva Yu.S, Osipenko A. Fracture Toughness Estimation by Means of Indentation Test. Mechanika, 2007, vol. 67, no. 5, pp. 33-36.

5. Baron A.A., Gevlich D.S., Bakhracheva Yu.S. Specific Plastic Strain Energy as a Measure of the Cracking Resistance of Structural Materials. Russian metallurgy (Metally), 2002, no. 6, pp. 587-592.

6. Basso L.H.M., Lima G.P.P., Gonsalves A.N., Vilhena S.M.C., Padilha C. do C.F. Efeito do alumínio no conteúdo de poliaminas livres e atividade da fosfatase ácida durante o crescimento de brotações de Eucalyptus grandis x E. urophylla cultivadas in vitro. Sciencia Forestalis, 2007, vol. 75, pp. 9-18.

7. Bednarek W., Reszka R. The Influence of Liming and Mineral Fertilization on the Utilization of Nitrogen by Spring Barley. Annales Universitatis Mariae Curie-Skłodowska, Lublin-Polonia, 2009, vol. 64, no. 3, pp. 11-20.

8. Blamey F.P.C., Edmeades D.C., Wheeler D.M. Empirical Models to Approximate Calcium and Magnesium Ameliorative Effects and Genetic Differences in Aluminum Tolerance In Wheat. Plant Soil, 1992, vol. 144, pp. 281-287.

9. Cordeiro A.T. Efeito de níveis de nitrato, amônio e alumínio sobre o crescimento e sobre a absorção de fósforo e de nitrogênio. Stylosanthes guianensis e Stylosanthes macrocephala. Viçosa, $1981.53 \mathrm{p}$.

10. Deletić N., Stojković S., Djurić V., Biberdžić M., Gudžić S. Genotypic Specificity of Winter Wheat Nitrogen Accumulation on an Acid Soil. Research Journal of Agricultural Sciences, 2010, vol. 42, no. 1, pp. 71-75.

11. Dong D., Peng X., Yan X. Organic Acid Exudation Induced by Phosphorus Deciency and/or Aluminium Toxicity in Two Contrasting Soybean Genotypes. Physiol. Plant., 2004, vol. 122, pp. 190199.

12. Eswaran H., Reich P., Beinroth F. Global Distribution of Soils With Acidity. Braz. Soil Sci. Soc., 1997, pp. 159-164.

13. Fleming A.L., Foy C.D. Root Structure Reflects Differential Aluminum Tolerance in Wheat Varieties. Agron. J., 1968, vol. 60, pp. 172-176.

14. Foy C.D. Tolerance of Barley Cultivars to an Acid, Aluminum-Toxic Subsoils Related to Mineral Element Concentrations in Their Shoots. J. Plant Nutrit., 1996, vol. 19, pp. 1361-1380.

15. Fukuda T., Saito A., Wasaki J., Shinano T., Osaki M. Metabolic Alterations Proposed by Proteome in Rice Roots Grown Under Low P and High Al Concentration Under Low pH. Plant Sci., 2007, vol. 172, pp. 1157-1165.

16. Gaume A., Machler F., Frossard E. Aluminum Resistance in Two Cultivars of Zea mays L: Root Exudation of Organic Acid and Inuence of Phosphorus Nutrition. Plant Soil., 2001, vol. 234, pp. 73-81.

17. Grauer U.E., Horst W.J. Effect of $\mathrm{pH}$ and $\mathrm{N}$ Source on Aluminum Tolerance of Rye (Secale cereale L.) and Yellow Lupin (Lupinus luteus L.). Plant Soil., 1990, vol. 127, pp. 13-21.

18. Guo T.R., Zhang G.P., Zhou M.X., Wu F.B., Chen J.X. Inuence of Aluminum and Cadmium Stresses on Mineral Nutrition and Root Exudates in Two Barley Cultivars. Pedosphere, 2007, vol. 17, pp. 505-512.

19. Habash D.Z., Bernard S., Schondelmaier J., Weyen J., Quarrie S.A. The Genetics of Nitrogen Use in Hexaploid Wheat: N Utilization, Development and Yield. Theor. Appl. Genet., 2007, vol. 114, pp. 403-419.

20. Hirel B., Le Gouis J., Ney B., Gallais A. The Challenge of Improving Nitrogen Use Efficiency in Crop Plants: Towards a More Central Role for Genetic Variability and Quantitative Genetics Within Integrated Approaches. J. Exp. Bot., 2007, vol. 58, pp. 2369-2387.

21. Hoagland D.R., Arnon D.I. The Water-Culture Method for Growing Plants Without Soil. Circ. 347, Calif. Agric. Exp. Stn., Berkeley, CA, 1950, pp. 35-37.

22. Homes M.V.L. Alimentation Minerale Equilibree Des Vegetaux. Wetteren, Universa, 1961, vol. $1.55 \mathrm{p}$.

23. Iqbal T., Sale P., Tang C. Phosphorus Ameliorates Aluminium Toxicity of Al-Sensitive Wheat Seedlings. $19^{\text {th }}$ World Congress of Soil Science, Soil Solutions for a Changing World 1-6 August 2010, Brisbane, Australia. 2010, pp. 92-95.

24. Jayasundara H.P.S., Thomson B.D., Tang C. Responses of Cool Season Grain Legumes to Soil Abiotic Stresses. Adv. Agron., 1998, vol. 63, pp. 77-151.

25. Jemo M., Abaidoo R.C., Nolte C., Horst W.J. Aluminum Resistance of Cowpea as Affected by Phosphorus-Deciency Stress. J. Plant Physiol., 2007, vol. 164, pp. 442-451.

26. Kochian L.V., Hoekenga O.A., Pineros M.A. How Do Crop Plants Tolerate Acid Soils? Mechanisms of Aluminum Tolerance and Phosphorous Efficiency. Annu. Rev. Plant Biol., 2004, vol. 55, pp. 459-493.

27. Le Gouis J., Fontaine J-X., Laperche A., Heumez E., Devienne-Barret F., Brancourt-Hulmel M., Dubois F., Hirel B. Genetic Analysis of Wheat Nitrogen Use Efficiency: Coincidence Between Qtl for Agronomical and Physiological Traits. Proceedings of the $11^{\text {th }}$ International Wheat Genetics Symposium, 2008. Aviable at: http://hdl.handle.net/ 2123/3217. 


\section{ТЕХНИКО-ТЕХНОЛОГИЧЕСКИЕ ИННОВАЦИИ}

28. Liang C., Piñeros M.A., Tian J., Yao Z., Sun L., Liu J., Shaff J., Coluccio A., Kochian L.V., Liao H. Low pH, Aluminum, and Phosphorus Coordinately Regulate Malate Exudation Through GmALMT1 to Improve Soybean Adaptation to Acid Soils. Plant Physiol., 2013, vol. 161, pp. 1347-1361.

29. Liao H., Wan H., Shaff J., Wang X., Yan X., Kochian L.V. Phosphorus and Aluminum Interactions in Soybean in Relation to Aluminum Tolerance: Exudation of Specic Organic Acids From Different Regions of the Intact Root System. Plant Physiol., 2006, vol. 141, pp. 674-684.

30. Lichtenthaler H.K., Buschmann C. Chlorophylls and Carotenoids - Measurement and Characterisation by UV-VIS. Current Protocols in Food Analytical Chemistry. John Wiley\&Sons, Madison, 2001, pp. F4.3.1-F4.3.8. [Nr. 107].

31. Lisitsyn E.M. Intravarietal Level of Aluminum Resistance in Cereal Crops. J. Plant Nutrition, 2000, vol. 23, no. 6, pp. 793-804.

32. Lisitsyn E.M., Batalova G.A. Aluminum Resistance of Direct and Reciprocal Oats F2 Hybrids. Herald of the Russian Academy of Agricultural Sciences, 2007, no. 1, pp. 47-49.

33. Lisitsyn E.M., Shchennikova I.N., Shupletsova O.N. Cultivation of Barley on Acid SodPodzolic Soils of North-East of Europe. Elfson S.B., ed. Barley: Production, Cultivation and Uses. New York, Nova Publ., 2011, pp. 49-92.

34. Malavolta E., Vitti G.C., Oliveira S.A. Avaliação do estado nutricional das plantas: princípios e aplicações. $2^{\text {nd }}$ ed. Potafos, Piracicaba, 1997.319p.

35. McCormick L.H., Borden F.Y. Phosphate bxation by Aluminium in Plant Roots. Soil Sci. Soc. Am. J., 1972, vol. 36, pp. 779-802.

36. Nakagawa T., Mori S., Yoshimura E. Amelioration of Aluminium Toxicity by Pre-Treatment With Phosphate in Aluminium-Tolerant Rice Cultivar. J. Plant Nutrit., 2003, vol. 26, pp. 619-628.

37. Olivares E., Pena E., Marcano E., Mostacero J., Aguiar G., Benitez M., Rengifo E. Aluminum Accumulation and Its Relationship With Mineral Plant Nutrients in 12 Pteridophytes From Venezuela. Env. Exp. Bot., 2009, vol. 65, pp. 132-141.

38. Pronina N.B., Ladonin V.F., eds. Physiological and Biochemical Methods of Studying the Action of Chemical Means Complex on Plants (Methodical Recommendations). Moscow, All-Russian Research Institute of Agrochemistry, 1988. 68 p.

39. Rinkis G.Ya., Nollendorf V.F. Balanced Nutrition of Plants With Macro- and Microelements. Riga, Apgāds “Zinātne”, 1982. 301 p.
40. Semenova L.M., Bakhracheva Yu.S., Semenov S.V. Laws of Formation of Diffusion Layers and Solution of the Diffusion Problem in TemperatureCycle Carbonitriding of Steel. Metal Science and Heat Treatment, 2013, vol. 55, no. 1-2, pp. 34-37.

41. Shapochkin V.I., Semenova L.M., Bakhracheva Yu.S., Gyulikhandanov E.L., Semenov S.V. Effect of Nitrogen Content on the Structure and Properties of Nitrocarburized Steel. Metal Science and Heat Treatment, 2011, vol. 52, no. 910, pp. 413-419.

42. Silva I.R., Smyth T.J., Israel D.W., RuftyT.W. Altered Aluminum Inhibition of Soybean Root Elongation in the Presence of Magnesium. Plant Soil, 2001, vol. 230, pp. 223-230.

43. Somers D.J., Gustafson J.P. The Expression of Aluminum Stress Induced Polypeptides in a Population Segregating for Aluminum Tolerance in Wheat (Triticum aestivum L.). Genome, 1995, vol. 38, pp. 1213-1220.

44. Stojković S. Genotipska variranja nekih pokazatelja akumulacije i iskorišćavanja suve materije $i$ azota kod ozime pšenice. Magistarska teza, Poljoprivredni fakultet, Univerzitet u Prištini. 2001. 120 p.

45. Sun Q.B., Shen R.F., Zhao X.Q., Chen R.F., Dong X.Y. Phosphorus Enhances Al Resistance in Alresistant Lespedeza bicolor but not in Al-Sensitive $L$. cuneata Under Relatively High Al Stress. Ann. Bot. (Lond), 2008, vol. 102, pp. 795-804.

46. Vakhmistrov D.B. Separate Estimation of Optimal Doze N+P+K and N:P:K Ratio in Fertilizer. 1. Foundation of Problem. Agrochemistry, 1982, no. 4, pp. 3-12.

47. Vakhmistrov D.B., Vorontsov V.A. Selective Ability of Plants is not Directed at Providing Their Maximum Growth. Russian Plant Physiology, 1997, vol. 44, no. 3, pp. 404-412.

48. Wagatsuma T., Kawashima T., Tamaraya K. Comparative Stainability of Plant Root Cells With Basic Dye (Methylene Blue) in Association With Aluminum Tolerance. Commun. Soil Sci. Plant Anal., 1988, vol. 19, pp. 1207-1215.

49. Zelensky M.I. Photosynthetic Characteristics of Major Agricultural Crops and Prospects of Their Breeding Application. Physiological Principles of Plant Breeding. Saint Petersburg, Publishing Office of VIR, 1995, pp. 466-554.

50. Zheng S.J., Yang J.L., He Y.F., Yu X.H., Zhang L., You J.F., Shen R.F., Matsumoto H. Immobilization of Aluminum With Phosphorus in Roots is Associated With High Aluminum Resistance in Buckwheat. Plant Physiol, 2005, vol. 138, pp. 297-303. 


\section{ОСОБЕННОСТИ МИНЕРАЛЬНОГО ПИТАНИЯ ЗЕРНОВЫХ В КИСЛЫХ ПОЧВЕННЫХ УСЛОВИЯХ}

\section{Шихова Людмила Николаевна}

Доктор сельскохозяйственных наук, доцент, заведующая кафедрой экологии и зоологии, Вятская государственная сельскохозяйственная академия shikhola-1@mail.ru Октябрьский просп., 133, 610017 г. Киров, Российская Федерация

\section{Лисицын Евгений Михайлович}

Доктор биологических наук, профессор кафедры экологии и зоологии, Вятская государственная сельскохозяйственная академия edaphic@mail.ru Октябрьский просп., 133, 610017 г. Киров, Российская Федерация

\section{Баталова Галина Аркадьевна}

Доктор сельскохозяйственных наук, профессор, заведующая отделом селекции овса, Вятская государственная сельскохозяйственная академия g.batalova@mail.ru Октябрьский просп., 133, 610017 г. Киров, Российская Федерация

Аннотация. В работе изучается влияние ионов алюминия на характеристики растений зерновых культур (пшеницы Triticum aestivum L. и овса Avena sativa L.). В ходе экспериментов выявлено, что удвоение дозы фосфора в кислых средах вызвало удвоение содержания ее в обменных процессах в пшенице Irgina на ранних стадиях развития, а в пшенице Приокская - только на стадии цветения.

Ключевые слова: яровая пшеница, овес, алюминий, азот, фосфор, калий. 